\title{
The Triple-negative Breast Cancer Cell Line MDA-MB 231 Is Specifically Inhibited by the Ionophore Salinomycin
}

\author{
THOMAS HERO ${ }^{1,2}$, HELMUT BÜHLER ${ }^{2}$, PASCALINE NGUEMGO KOUAM ${ }^{2}$, \\ BETTINA PRIESCH-GRZESZOWIAK ${ }^{2}$, TATIANA LATEIT ${ }^{3}$ and IRENÄUS ANTON ADAMIETZ ${ }^{1,2}$ \\ ${ }^{1}$ Clinic for Radiation Oncology and Radiotherapy, Marien Hospital Herne, \\ Department of the Ruhr University Bochum, Herne, Germany; \\ ${ }^{2}$ Institute for Molecular Oncology, Radiobiology and Experimental Radiotherapy, \\ Department of the Ruhr University Bochum, Herne, Germany; \\ ${ }^{3}$ Clinic for Radiation Oncology and Radiotherapy, St. Josef Hospital Bochum, \\ Department of the Ruhr University Bochum, Herne, Germany
}

\begin{abstract}
Background/Aim: Tumour cells of the profile $\mathrm{CD} 44^{+} / \mathrm{CD} 24^{\text {low/- }}$ have a high tumorigenic potential. Salinomycin can specifically inhibit the growth of these cells. Herein, we investigated the effects of salinomycin on the viability and migration of triple negative breast cancer cells. Materials and Methods: We analysed two cell lines: i) triplenegative MDA-MB 231 breast cancer cells and ii) a cytokeratin 18-transfected, re-differentiated subclone of the $M D A-M B 231$ cell line. The viability was determined using an MTT (3-14,5-dimethylthiazol-2-yl)-2,5-diphenyltetrazolium bromide) test, and the migration was determined using $24-h$ videography. The expression of oestrogen receptor was determined using immunohistochemistry. Results: Salinomycin reduces all migration parameters in MDA-MB 231 cells. A significant correlation was found between increasing salinomycin concentrations and loss of cell viability, which was significantly less noticeable in the transfected control cells. Conclusion: With salinomycin there is a specific inhibition of MDA-MB 231 cells. Since MDA-MB 231 has over $90 \%$ cells with the profile $C D 44^{+} / C D 24^{\text {low/- }}$, these might represent a possible point of attack for salinomycin.
\end{abstract}

Breast cancer is one of the most common malignant diseases in women, with more than a million new cases every year worldwide (1). Immunohistochemical criteria as well as gene

Correspondence to: Helmut Bühler, Institute for Molecular Oncology, Radiobiology, and Experimental Radiotherapy, Department of the Ruhr University Bochum, Düngelstraße 33, D-44623 Herne, Germany. Tel: +49 23234991058, Fax: +49 23234991059, email: helmut.buehler@rub.de

Key Words: Breast cancer, TNBC, ionophore, salinomycin, motility, migration, proliferation, CSC. expression profile analyses allow a refined classification of this disease entity (2). Depending on the case, specific therapy can target hormones $(3,4)$ or use targeted antibodies, such as Trastuzumab used in cases of HER2/neu overexpression (5).

Triple negative breast cancer cells neither present with an expression of oestrogen or progesterone receptors, nor an overexpression of HER2, such that anti-hormonal and targeted therapies are not promising (6).

In order to explain the formation of malignant tumours, a new focus of research has led to the cancer stem cell hypothesis. This hypothesis was first postulated in 1997 by Bonnet and Dick with respect to acute myeloid leukaemia and in 2003 it was also applied to breast cancer. According to this, breast cancer cells with surface profile $\mathrm{CD} 44^{+} / \mathrm{CD} 24^{\text {low/- }}$ have a considerably higher tumorigenic potential $(7,8)$, and they are in high proportion (9).

Salinomycin is a carboxylic ionophor with an antibiotic effect, which can specifically transport monovalent positive ions, with a preference for potassium ions, across biological membranes (10). It has already been used for decades in poultry farming to prevent coccidiosis and as a food supplement in breeding pigs and cows to stimulate their growth $(11,12)$. In 2009 , a specific cytotoxic effect of salinomycin on breast cancer cells with the surface marker profile $\mathrm{CD} 44^{+} / \mathrm{CD} 24^{\text {low/- }}$ was demonstrated (13).

The breast cancer cell line MDA-MB 231 is a triplenegative cell line with a mesenchymal phenotype with over $90 \%$ of the total population expressing $\mathrm{CD} 44^{+} / \mathrm{CD} 24^{\text {low } /-}$ (14). With regard to the findings of Gupta et al., a clear inhibitory effect of salinomycin could also be expected in MDA-MB 231 cells. The aim of this study was, therefore, to investigate whether salinomycin actually significantly inhibits these cells. This would then possibly open up a new option in the therapy of the triple negative breast carcinoma, which is difficult to treat so far. 


\section{Materials and Methods}

Cell lines. The experiments were carried out on the established triple negative breast cancer cell line MDA-MB 231. As a control group we used a re-differentiated subclone of MDA-MB 231 cells, which were transfected with cytokeratin (CK)-18 expressing vector (15). In addition, MCF7 breast cancer cells served as a positive control for the expression of the oestrogen receptor.

Videography. Motility parameters were analysed with a selfconstructed videography system as described previously (16). For a videography sequence, the cells were seeded into $35 \mathrm{~mm}$ Petri dishes, at a density of 16,000 cells per dish. The influence of salinomycin on the motility of the two cell lines was investigated at the following concentrations: i) $5 \times 10^{-7}$, ii) $10^{-6}$, iii) $5 \times 10^{-6}$, iv) $10^{-5}$ and v) $5 \times 10^{-5} \mathrm{~mol} / \mathrm{l}$. The videography apparatus was constructed on top of an inverted microscope connected to a digital camera. Instead of the XY table, a climatised chamber was attached, in which, inside a six-hole tray, a maximum of 6 individual Petri dishes measuring $35 \times 10 \mathrm{~mm}$ could be placed. The chamber was gassealed and the temperature was stabilised at $37^{\circ} \mathrm{C}$. The chamber could move freely along all three axes using linear motors. The control software made it possible to select the number of fields of view, which could be photographed at any chosen time point. The motility of the cells was observed over $24 \mathrm{~h}$. Three fields of view with approximately 20-30 cells in each field were chosen and photographed at 15-min intervals. The image data from each field of view were evaluated. Following tracking, the following parameters of cell behaviour were analysed using the "Chemotaxis and Migration Tool”, provided by Ibidi (ibidi GmbH, Gräfelfing, Germany) (https://ibidi.com/chemotaxis-analysis/171-chemotaxisand-migration-tool.html): i) cell migration speed (V) $(\mu \mathrm{m} / \mathrm{min})$, ii) Euclidean distance (ED) $(\mu \mathrm{m} / 24$ hours $)$ and iii) accumulated distance (AD) $(\mu \mathrm{m} / 24$ hours).

Immunostaining of the oestrogen receptor (ER). The cells were seeded on glass cover slips and were fixed the next day with ice-cold MAF (47.5\% methanol, $47.5 \%$ acetone, $5 \%$ formalin (10\% in PBS buffer) for 30 minutes at room temperature. The cells were subsequently incubated with a monoclonal rabbit anti-ER antibody (1:100, Neomarkers SP1 RM9101, Thermo-Fisher, Dreieich, Germany) for $1 \mathrm{~h}$ at $37{ }^{\circ} \mathrm{C}$, followed by incubation with a biotinylated goat anti-rabbit-IgG antibody (1:400, Jackson IR 111-065-003, Biozol, Eching, Germany), and finally with a streptavidin-AP conjugate (1:400, 11112481 001, Roche Diagnostics, Mannheim, Germany). The AP colour reaction to detect ER was performed using the Dako Liquid Permanent Red kit (KO640, Agilent-Dako, Hamburg, Germany), according to the manufacturer's instructions.

Inhibition of proliferation by salinomycin. A standard MTT (3-(4,5dimethylthiazol-2-yl)-2,5-diphenyltetrazolium bromide) assay was performed to determine the proliferation rate as described earlier (17). The cells were seeded at a density of 5,000 cells/well into a 96-well plate. The influence of salinomycin (S4526, Sigma-Aldrich, Taufkirchen, Germany) on the proliferation of the cells was evaluated in the following concentrations: i) $10^{-7}$, ii) $5 \times 10^{-7}$, iii) $10^{-6}$, iv) $5 \times 10^{-6}$, v) $10^{-5}$, vi) $1.25 \times 10^{-5}$, vii) $2.5 \times 10^{-5}$, viii) $5 \times 10^{-5}$, ix) $7.5 \times 10^{-5}$, x) $10^{-4}$, and $\left.\mathrm{xi}\right) 5 \times 10^{-4} \mathrm{~mol} / \mathrm{l}$. The cell viability was determined after 72 hours. These experiments were performed in triplicates.
Statistical analysis. The statistical evaluation was carried out in Prism 5.0 (Graph Pad Inc., La Jolla, CA, USA), using the $t$-test for unpaired samples and regression analysis.

\section{Results}

The transfection of a cytokeratin 18-expressing vector into MDA-MB 231 cells led, as previously described, not only to the recovery of the keratin expression lost due to the malignant transformation, but also to the re-establishment of E-cadherin expression and of other adhesion molecules (15). We now show in this study that the CK18-transfected cells also express the oestrogen receptor in contrast to the ER negative wild type. As shown in Figure 1, the oestrogen receptor expression is comparably as strong as in the ER-positive MCF7 cell line. This MDA-MB-231 subclone is, therefore, an ideal control for the investigations presented here.

Migration speed $(V)$. When salinomycin was used in MDAMB 231 cells, a very significant $(p<0.0001)$ loss of their migration speed was visible, even with the minimum concentration of $5 \times 10^{-7} \mathrm{~mol} / \mathrm{l}$.

On the contrary, salinomycin in cells transfected with $\mathrm{CK}$ 18 had no such effect (Figure 2).

Accumulated distance $(A D)$. As expected, under the influence of salinomycin, in MDA-MB 231 cells there was a very significant decline in accumulated distance $(p<0.0001)$, while no inhibiting effect was observed in the control group (Figure 3).

Euclidean distance (ED). Unlike the migration speed and the accumulated distance, a statistically significant decline $(p<0.05)$ in this parameter could only be seen in the MDAMB 231 cells with a starting salinomycin concentration of $10^{-5} \mathrm{~mol} / \mathrm{l}$ and upwards. No inhibiting effect was seen in the control group (Figure 4).

Cell viability. For the direct comparison of the cell viability in the control group transfected with CK 18 , the calculation of $\mathrm{IC}_{50}$ (half maximal inhibitory concentration) was carried out using regression analysis. Following $24 \mathrm{~h}$ of incubation with salinomycin, the concentration of the drug had to be 60-times higher in the cells transfected with $\mathrm{CK} 18$ to reach $\mathrm{IC}_{50}$ compared to the undifferentiated MDA-MB 231 cells. Following a 72-h incubation with salinomycin, the cells transfected with CK 18 required a 10-times higher concentration of the drug to reach $\mathrm{IC}_{50}$ compared to the MDA-MB 231 cells (Figure 5).

\section{Discussion}

The inhibiting effect of salinomycin on tumour cells with stem cell properties has been known since the work of Gupta et al., and it has since been extended on additional tumour 


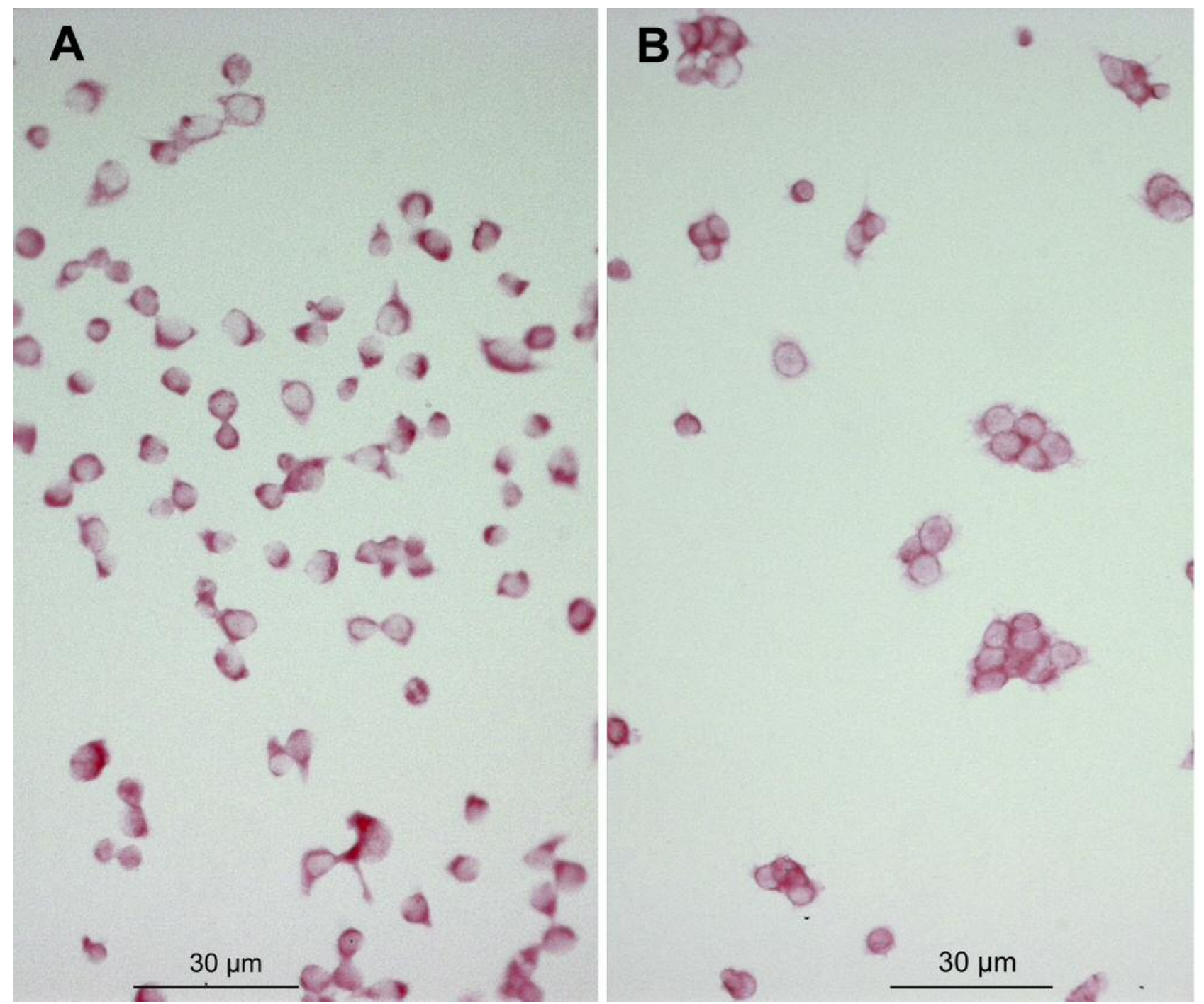

Figure 1. Immunostaining of the oestrogen receptor in MDA-MB 231 (CK18) cells (A) and the positive control, MCF-7 cells (B), using an anti-ER antibody (red). Scale bars: $30 \mu \mathrm{m}$.

entities, such as osteosarcoma (18) and endometrial cancer (19). These studies suggest that salinomycin enacts in a specific manner on tumour cells with stem cell properties. MDA-MB 231 is a triple negative cell line with poor differentiation and with a mesenchymal phenotype, along with a high expression of vimentin and an associated highly invasive behaviour (20). The tumour stem cell markers of breast cancer, according to Al-Hajj et al., involve a combination of the surface markers $\mathrm{CD} 44^{+} / \mathrm{CD} 24^{\text {low/- }}$ (8). Admittedly, according to Fillmore and Kuperwasser, MDAMB 231 cells present the aforementioned surface marker profile in a proportion of more than $90 \%$ of the total population, a finding which has also been confirmed by other investigators, however, it may not be sufficient for an aggressive tumour-inducing effect $(21,22)$. Interestingly, another cell population with the marker profile $\mathrm{CD} 44^{+} / \mathrm{CD} 24^{\text {low/- }} \mathrm{ESA}^{+}$may have a higher tumour-inducing potential, however, the fraction of these cells constitutes approximately only $2 \%$ of the total cell mass (21).

The aim of this work was to investigate the degree to which cell viability and migration of the triple-negative breast cancer cell line MDA-MB 231 are influenced by salinomycin. As a control group we used the re-differentiated subclone of MDAMB 231 cells transfected with CK18. In migration tests using various cell lines, including MDA-MB 231, Kopp et al., were able to demonstrate an inhibition of migration ability with salinomycin, using either the Boyden chamber assay or the scratch assay (23). Based on these results, it was assumed that 


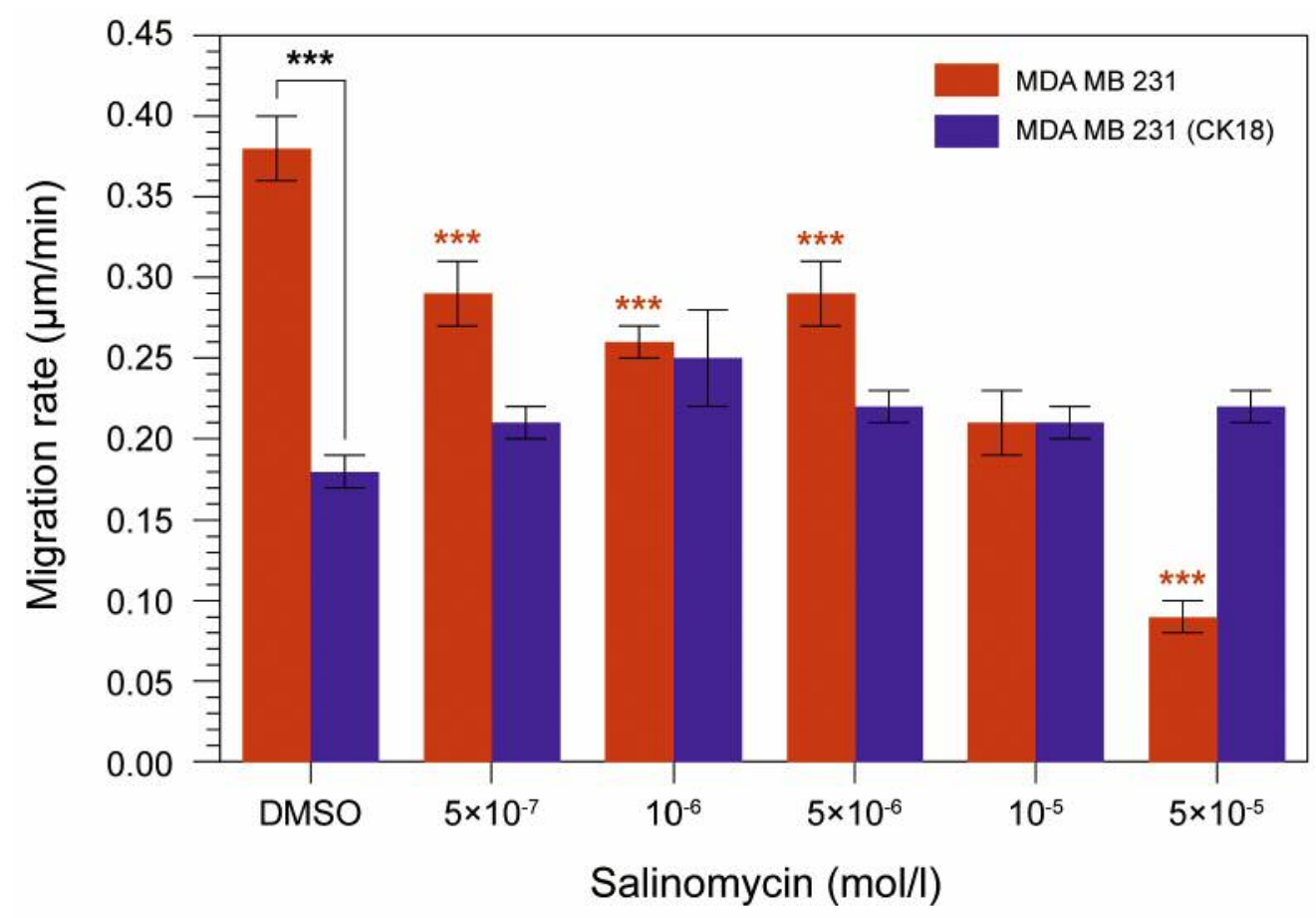

Figure 2. Migration rate of cells following incubation with salinomycin. The triple-negative MDA-MB 231 cells are strongly inhibited depending on the dose, while the ionophore has no significant influence on the migratory speed of the ER-expressing cells. Mean values \pm S.E.M. are shown. Red bars: MDA-MB 231 wild type, blue bars: MDA-MB 231 (CK18). ***p<0.001; n=6-9.

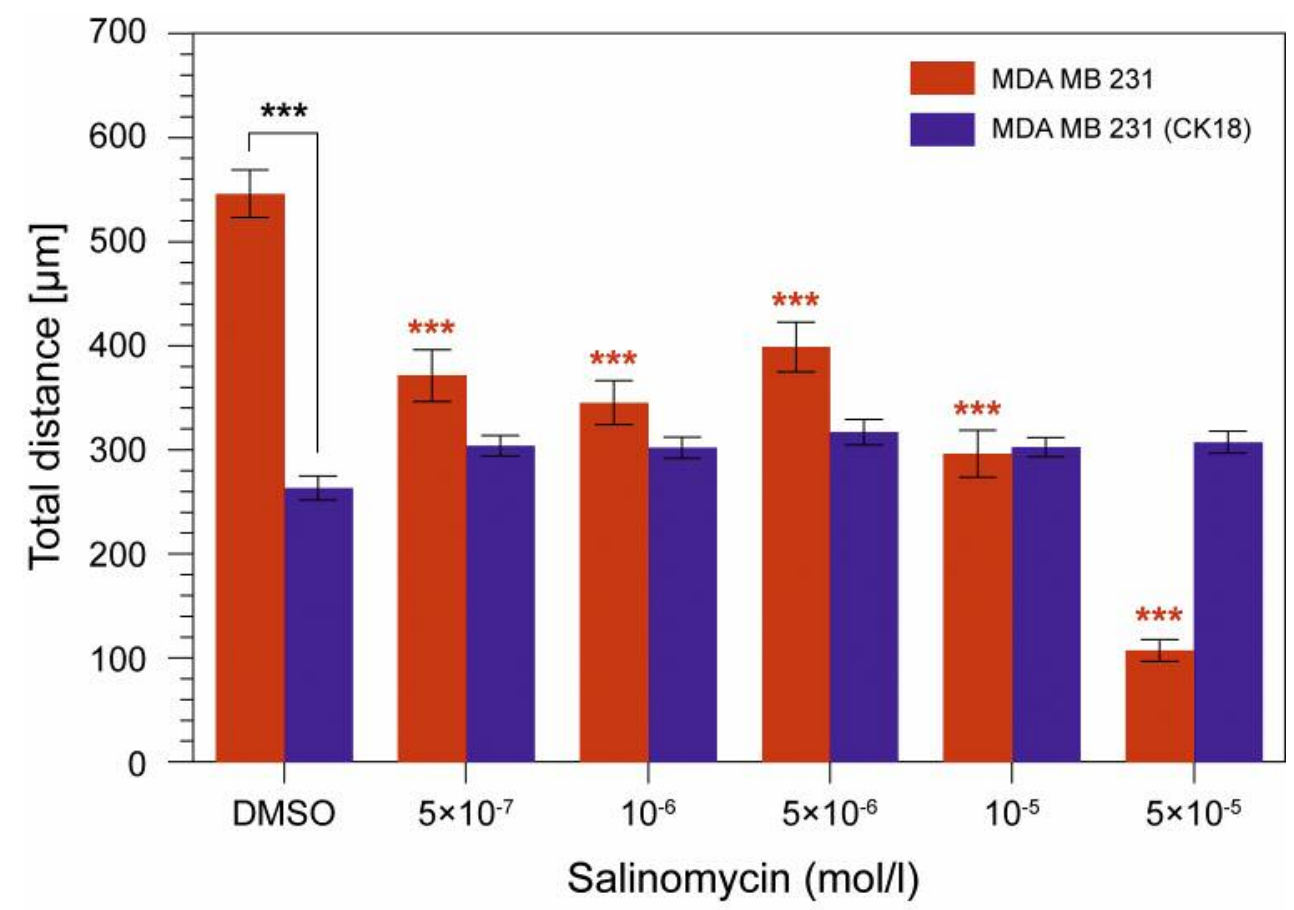

Figure 3. Total distance travelled by the cells following incubation with salinomycin. The cells were observed by time-lapse videography over 24 hours and the distance covered was analysed. The total distance of the triple negative MDA-MB 231 cells is significantly decreased by salinomycin in a dose-dependent manner, whereas the ER-expressing cells are not affected. Mean values \pm S.E.M. are shown. Red bars: MDA-MB 231 wild type, blue bars: $M D A-M B 231$ (CK18). ***p<0.001; $n=6-9$. 


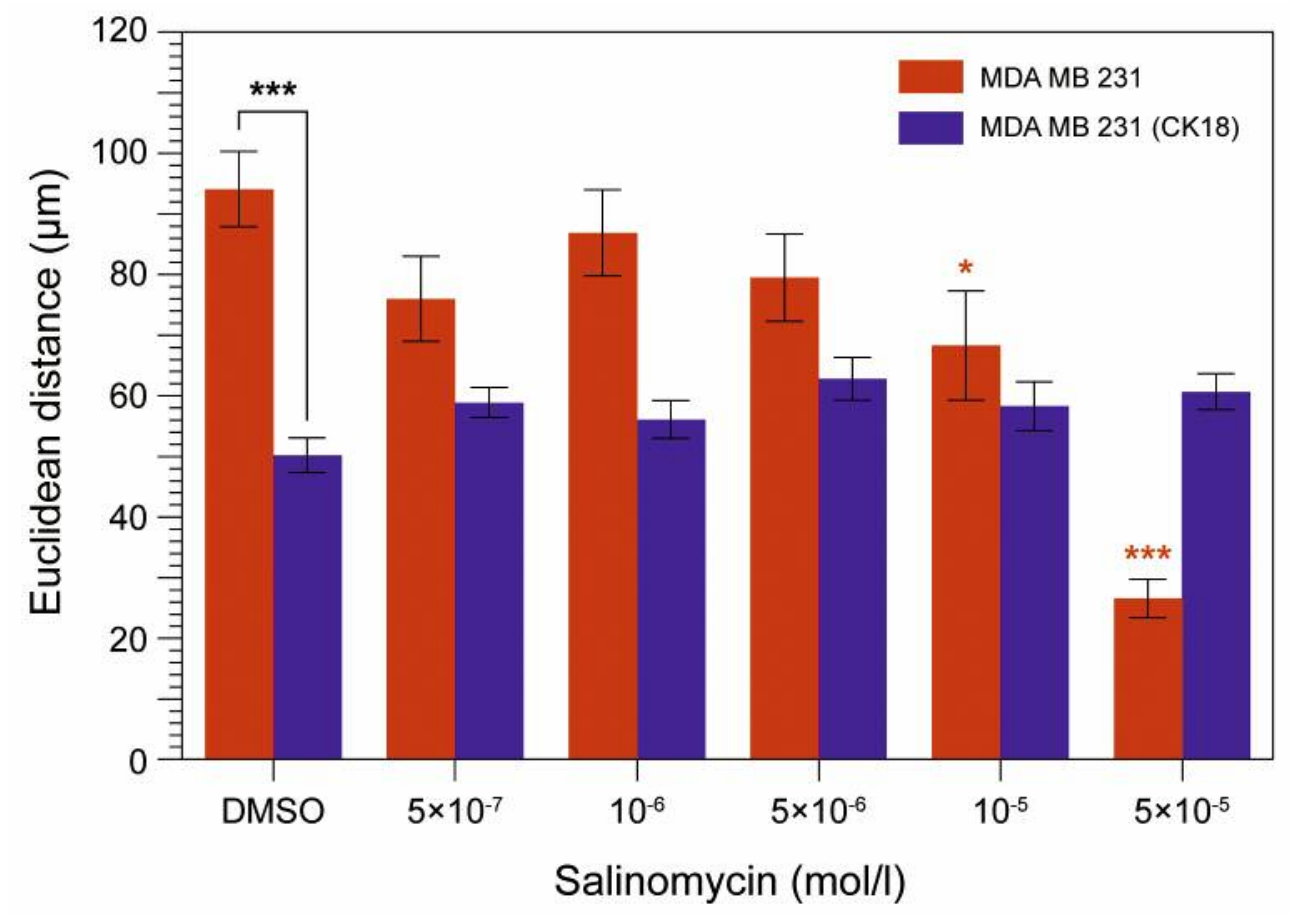

Figure 4. Euclidean distance of the cells following incubation with salinomycin. The cells were observed by time-lapse videography over 24 h and the distance of each cell's trajectory from its original position to the final point was analysed. The distance that MDA-MB 231 cells travelled was reduced by salinomycin in a dose-dependent manner, albeit at a less significant level compared to the accumulated distance. The Euclidean distance of the ER-expressing cells was not significantly affected by salinomycin. Mean values \pm S.E.M. are shown. Red bars: MDA-MB 231 wild type, blue bars: $M D A-M B 231$ (CK18). *p<0.05;***p<0.001; $n=6-9$.

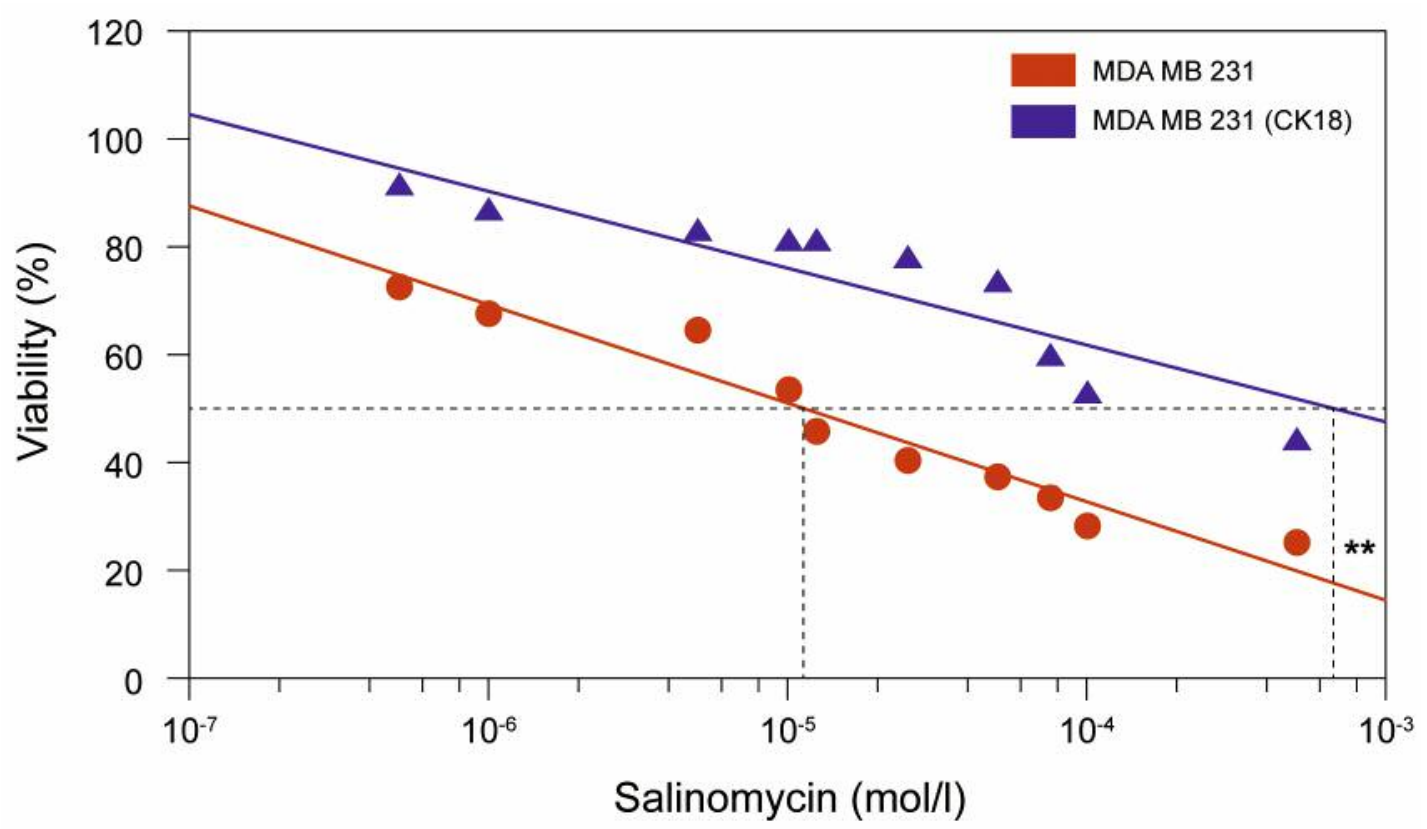

Figure 5. Proliferation rates are reduced by salinomycin. Regression analysis of the normalised mean values of 3 independent experiments shows that salinomycin reduces the proliferation rate in both cell lines, with the MDA-MB 231 cells $\left(I C_{50}=10^{-5}\right)$ being significantly more affected compared to the ER-positive MDA-MB 231 cells $\left(I C_{50}=6 \times 10^{-4}\right)$ (the black dotted line points where $I_{50}$ is reached in both cases). Red circles: $M D A-M B 231$ wild type; blue bars: $M D A-M B 231$ (CK18). **p<0.01. 
in addition to tumour stem cells, other types of tumour cells with no defined stem cell characteristics (e.g. tumour induction) could also be inhibited by salinomycin in their migratory potential (23). The results found in this study confirm the assumptions of Kopp et al. Using videography gives more reliable results compared to the other two methods (migration in the Boyden chamber and the scratch assay), as it specifically measures the migration potential of the cells investigated. Specifically, in transwell experiments, a cytokine gradient must be created for the cells to migrate through the membrane. This means that what is measured is, therefore inevitably, always a mixture of migration and chemotaxis. In the scratch assay, the wound is not only closed by migrating cells, but also by the proliferating cells at the edges. Such side effects, which falsify the migration values, are not to be expected in the analyses that use data from videography. Using 24hour videography, a salinomycin concentration range between $5 \times 10^{-7} \mathrm{~mol} / \mathrm{l}$ and $5 \times 10^{-5} \mathrm{~mol} / \mathrm{l}$ demonstrated a statistically significant decline in all three migration parameters (V, AD and ED) in MDA-MB 231 cells. Similar results were shown with respect to the cell viability. For both cell lines (MDA-MB 231 and MDA-MB 231 (CK18) a highly significant correlation could be demonstrated between an increasing salinomycin concentration and a decrease in cell viability, a finding which is also supported by the viability studies by An et al. (24). The obtained $\mathrm{IC}_{50}$ values show that MDA-MB 231 CK18 cells have a significantly higher tolerance to salinomycin than MDA-MB 231 cells. Since salinomycin exerts a clear inhibition of the motility parameters even at the smallest concentration studied, the analyses should possibly be refined to lower doses.

According to Fillmore and Kuperwasser, the MDA-MB 231 cell line presents stem cell properties in only a $2 \%$ of the total population, while a major effect was obvious in a large proportion of cells. Taken together, our results suggest that salinomycin also acts effectively in cells with no stem cell properties.

The present work shows that the specific inhibition of cancer stem cells by salinomycin, previously described by Gupta et $a l .$, is also effective in breast cancer cells of the triple negative subtype. Ionophores, such as salinomycin, may therefore potentially be an option for the therapy of this tumour entity, which is otherwise difficult to access medicinally.

\section{Conflicts of Interest}

The Authors declare that they have no conflict of interest.

\section{Authors' Contributions}

TH carried out the experiments with help of BPG. TH also prepared the manuscript with help of HB who designed the study. PNK and TL tracked the cells, IA and HB supervised the work. All Authors read and approved the final manuscript.

\section{Acknowledgements}

The Authors would like to thank the Stiftungsfonds BIOX for supporting this work.

\section{References}

1 McPherson K, Steel CM and Dixon JM: ABC of breast diseases. Breast cancer-epidemiology, risk factors, and genetics. BMJ 321 : 624-628, 2000. PMID: 10977847.

2 Scope A, Essat M, Pandor A, Rafia R, Ward SE, Wyld L, Cross $\mathrm{S}$ and Woods HB: Gene expression profiling and expanded immunohistochemistry tests to guide selection of chemotherapy regimens in breast cancer management: A systematic review. Int J Technol Assess Health Care 33: 32-45, 2017. PMID: 28486999. DOI: $10.1017 / \mathrm{S} 0266462317000034$

3 Awan A and Esfahani K: Endocrine therapy for breast cancer in the primary care setting. Curr Oncol 25: 285-291, 2018. PMID: 30111969. DOI: $10.3747 /$ co.25.4139

4 Castrellon AB: Novel strategies to Improve the endocrine therapy of breast cancer. Oncol Rev 11: 323, 2017. PMID: 28584571. DOI: 10.4081/oncol.2017.323

5 Guiu S, Michiels S, André F, Cortes J, Denkert C, Di Leo A, Hennessy BT, Sorlie T, Sotiriou C, Turner N, Van de Vijver, M, Viale G, Loi S and Reis-Filho JS: Molecular subclasses of breast cancer: how do we define them? The IMPAKT 2012 Working Group Statement. Ann Oncol 23: 2997-3006, 2012. PMID: 23166150. DOI: $10.1093 /$ annonc/mds586

6 Engebraaten O, Vollan, Hans Kristian Moen and Børresen-Dale A: Triple-negative breast cancer and the need for new therapeutic targets. Am J Pathol 183: 1064-1074, 2013. PMID: 23920327. DOI: 10.1016/j.ajpath.2013.05.033

7 Bonnet D and Dick JE: Human acute myeloid leukemia is organized as a hierarchy that originates from a primitive hematopoietic cell. Nat Med 3: 730-737, 1997. PMID: 9212098 .

8 Al-Hajj M, Wicha MS, Benito-Hernandez A, Morrison SJ and Clarke MF: Prospective identification of tumorigenic breast cancer cells. Proc Natl Acad Sci USA 100: 3983-3988, 2003. PMID: 12629218. DOI: 10.1073/pnas.0530291100

9 Ma F, Li H, Wang H, Shi X, Fan Y, Ding X, Lin C, Zhan Q, Qian H and Xu B: Enriched CD44(+)/CD24(-) population drives the aggressive phenotypes presented in triple-negative breast cancer (TNBC). Cancer Lett 353: 153-159, 2014. PMID: 25130168. DOI: 10.1016/j.canlet.2014.06.022

10 Antoszczak M, Huczyński A: Anticancer activity of polyether Ionophore-salinomycin. Anticancer Agents Med Chem 15: 575591, 2015. PMID: 25553435.

11 Miyazaki Y, Shibuya M, Sugawara H, Kawaguchi O and Hirsoe C: Salinomycin, a new polyether antibiotic. J Antibiot (Tokyo) 27: 814-821, 1974. PMID: 4452657.

12 Kinashi H, Otake N, Yonehara H, Sato S and Saito Y: The structure of salinomycin, a new member of the polyether antibiotics. Tetrahedron Lett 14: 4955-4958, 1973. DOI: 10.1016/S0040-4039(01)87382-2

13 Gupta PB, Onder TT, Jiang G, Tao K, Kuperwasser C, Weinberg RA and Lander ES: Identification of selective inhibitors of cancer stem cells by high-throughput screening. Cell 138: 645659, 2009. PMID: 19682730. DOI: 10.1016/j.cell.2009.06.034 
14 Fillmore CM and Kuperwasser C: Human breast cancer cell lines contain stem-like cells that self-renew, give rise to phenotypically diverse progeny and survive chemotherapy. Breast Cancer Res 10: R25, 2008. PMID: 18366788. DOI: $10.1186 /$ bcr 1982

15 Bühler H and Schaller G: Transfection of keratin 18 gene in human breast cancer cells causes induction of adhesion proteins and dramatic regression of malignancy in vitro and in vivo. Mol Cancer Res 3: 365-371, 2005. PMID: 16046547. DOI: 10.1158/1541-7786.MCR-04-0117

16 Buhler H, Adamietz R, Abeln T, Diaz-Carballo D, NguemgoKouam P, Hero T and Adamietz IA: Automated multichamber time-lapse videography for long-term in vivo observation of migrating cells. In Vivo 31: 329-334, 2017. PMID: 28438859 DOI: 10.21873 /invivo.11063

17 Krcek R, Matschke V, Theis V, Adamietz IA, Bühler H and Theiss C: Vascular endothelial growth factor, irradiation, and axitinib have diverse effects on motility and proliferation of glioblastoma multiforme cells. Front Oncol 7: 182, 2017. PMID: 28879167. DOI: 10.3389/fonc.2017.00182

18 Tang Q, Zhao Z, Li J, Liang Y, Yin J, Zou C, Xie X, Zeng Y, Shen J, Kang T and Wang J: Salinomycin inhibits osteosarcoma by targeting its tumor stem cells. Cancer Lett 311: 113-121, 2011. PMID: 21835542. DOI: 10.1016/j.canlet.2011.07.016

19 Kusunoki S, Kato K, Tabu K, Inagaki T, Okabe H, Kaneda H, Suga S, Terao Y, Taga T and Takeda S: The inhibitory effect of salinomycin on the proliferation, migration and invasion of human endometrial cancer stem-like cells. Gynecol Oncol 129: 598-605, 2013. PMID: 23500085. DOI: 10.1016/j.ygyno 2013.03.005
20 Thompson EW, Paik S, Brünner N, Sommers CL, Zugmaier G, Clarke R, Shima TB, Torri J, Donahue S and Lippman ME: Association of increased basement membrane invasiveness with absence of estrogen receptor and expression of vimentin in human breast cancer cell lines. J Cell Physiol 150: 534-544, 1992. PMID: 1537883. DOI: 10.1002/jcp.1041500314

21 Fillmore C and Kuperwasser C: Human breast cancer stem cell markers CD44 and CD24: enriching for cells with functional properties in mice or in man? Breast Cancer Res 9: 303, 2007. PMID: 17540049 . DOI: $10.1186 /$ bcr 1673

22 Borgna S, Armellin M, Di Gennaro A, Maestro R and Santarosa M: Mesenchymal traits are selected along with stem features in breast cancer cells grown as mammospheres. Cell Cycle 11: 4242-4251, 2012. PMID: 23095640. DOI: 10.4161/cc.22543

23 Kopp F, Hermawan A, Oak PS, Herrmann A, Wagner E and Roidl A: Salinomycin treatment reduces metastatic tumor burden by hampering cancer cell migration. Mol Cancer 13: 16, 2014. PMID: 24468090. DOI: 10.1186/1476-4598-13-16

24 An H, Kim JY, Oh E, Lee N, Cho Y and Seo JH: Salinomycin Promotes Anoikis and Decreases the CD44+/CD24- Stem-Like population via Inhibition of STAT3 activation in MDA-MB-231 cells. PloS One 10: e0141919, 2015. PMID: 26528725. DOI: 10.1371/journal.pone. 0141919

Received January 21, 2019

Revised May 15, 2019

Accepted May 17, 2019 